\title{
HUBUNGAN KEPEMIMPINAN EFEKTIF KEPALA RUANGAN DENGAN KINERJA PERAWAT DALAM MELAKUKAN ASUHAN KEPERAWATAN DI RSU SARI MUTIARA LUBUK PAKAM
}

\author{
Eva Kartika Hasibuan, Masri Saragih \\ Program Studi Ners Fakultas Farmasi dan Ilmu Kesehatan, Universitas Sari Mutiara Indonesia \\ E-mail : evakartikahsb86@gmail.com \\ Program Studi Ners Fakultas Farmasi dan Ilmu Kesehatan, Universitas Sari Mutiara Indonesia \\ E-mail : masri_saragih@ymail.com
}

\begin{abstract}
Effective leadership is required by the head of the room to create a good performance on nurses to achieve the purpose of the room is provide good and quality health serviceThis study aims to determine the effective leadership of head room with the performance of nurses in nursing care at RSU. Sari Mutiara Lubuk Pakam. Researchers used descriptive research method correlation with cross-sectional approach. The population in this study nurse who was on duty in the inpatient unit RSU. Sari Mutiara Lubuk Pakam totaling 55 people. The sample in this study used a total sampling technique with 55 respondents. The data collection technique using a questionnaire given to respondents. The results of this study are analyzed in univariate effective leadership of head room $(81.8 \%)$ with sufficient performance of nurses $(50.9 \%)$. After bivariate analysis with chi-square test showed that there is a relationship effective leadership of head room with the performance of nurses $(p$-value $=0.003)$. This study recommends that the head of the room more attention to implementation of the tasks of nursing care by nurses, as well as providing support in working order, the better the performance of nurses.
\end{abstract}

Keywords : Effective Leadership, Performance Nurse

\begin{abstract}
Abstrak
Kepemimpinan efektif diperlukan oleh kepala ruangan dalam menciptakan kinerja yang baik pada perawat pelaksana untuk mencapai tujuan ruangan yaitu memberikan pelayanan kesehatan yang baik dan berkualitas. Penelitian ini bertujuan untuk mengetahui kepemimpinan efektif kepala ruangan dengan kinerja perawat dalam melakukan asuhan keperawatan di RSU. Sari Mutiara Lubuk Pakam. Peneliti menggunakan metode penelitian deskriptif korelasi dengan pendekatan cross-sectional. Populasi dalam penelitian ini seluruh perawat pelaksana yang sedang bertugas RSU Sari Mutiara Lubuk Pakam berjumlah 55 responden. Sampel dalam penelitian ini menggunakan teknik total sampling dengan jumlah responden sebanyak 55. Teknik pengumpulan data menggunakan kuisioner yang diberikan kepada responden. Uji statistik yang digunakan dalam penelitian ini adalah uji chi-square. Hasil penelitian ini dianalisis secara univariat yaitu kepemimpinan kepala ruangan efektif $(81,8 \%)$ dengan kinerja perawat cukup $(50,9 \%)$. Setelah dilakukan analisis bivariat dengan uji chi-square didapatkan hasil yaitu ada hubungan kepemimpinan efektif kepala ruangan dengan kinerja perawat $(p-v a l u e=0,003)$. Penelitian ini merekomendasikan agar kepala ruangan lebih memperhatikan pelaksanaan tugas asuhan keperawatan oleh perawat, serta memberikan dukungan dalam bekerja agar kinerja perawat semakin baik.
\end{abstract}

Kata Kunci : Kepemimpina Efektif, Kinerja Perawat 


\section{PENDAHULUAN}

Sumber daya manusia dapat menjadi suatu aset dalam memberikan nilai tambah pada sebuah organisasi. Sumber daya manusia ini perlu dikelola secara efektif sehingga diperlukan suatu kepemimpinan yang efektif (Muninjaya, 2004). Kepemimpinan yang efektif dapat mempengaruhi orang-orang untuk bergerak dalam tujuan yang sama bukan karena diperintah tetapi membuat mereka mau bergerak dengan kemauan mereka sendiri. Untuk itu seorang pemimpin harus mampu membangun komitmen dari kelompoknya yaitu dengan cara memberi motivasi, semangat, dan kerja tim (Tappen, Weiss \& Whitehead, 2004).

Kepemimpinan yang diterapkan dalam suatu organisasi dapat membantu menciptakan efektivitas kerja yang positif bagi pegawai. Adanya kepemimpinan yang sesuai dengan situasi dan kondisi organisasi maka pegawai akan lebih semangat dalam menjalankan tugas dan kewajibannya dan mempunyai harapan terpenuhinya kebutuhan. Selain kepemimpinan, komunikasi intern juga mempunyai peranan yang sangat penting dalam mewujudkan efektivitas kerja yang positif. Komunikasi intern adalah proses penyampaian pesan-pesan yang berlangsung antar anggota organisasi, dapat berlangsung antara pimpinan dengan bawahan, pimpinan dengan pimpinan, maupun bawahan dengan bawahan. Demikian juga pada organisasi rumah sakit, kepemimpinan dan proses komunikasi kepala ruang perawatan dengan perawat pelaksana akan menentukan bagaimana kinerja perawat pelaksana dalam menjalankan tugas dan kewajibannya melalui asuhan keperawatan untuk memenuhi kebutuhan pasien (Nazlah, 2012).

Faktor kepemimpinan dalam organisasi memegang peranan penting, karena bawahan bekerja tergantung dari kemampuan pimpinannya. Pemimpin yang efektif akan mampu menularkan optimisme dan pengetahuan yang dimilikinya dalam mencapai tujuan organisasi. Perawat tidak memiliki uraian tugas dan belum dikembangkan monitoring dan evaluasi kinerja perawat khususnya mengenai keterampilan, sikap, kedisiplinan dan motivasi kerjanya (Jaiz, 2007). Penelitian tentang waktu kerja produktif personil rumah sakit di Indonesia ditemukan bahwa waktu kerja produktif personil adalah 53,2\% dan sisanya $46,8 \%$ digunakan untuk kegiatan non produktif. Dari 53,2\% kinerja produktif, hanya $13,3 \%$ waktu yang digunakan untuk kegiatan pelayanan kesehatan, sedangkan sisanya 39,9\% digunakan untuk kegiatan penunjang pelayanan kesehatan (Ilyas, 2001). Profesi keperawatan merupakan profesi yang memiliki sumber daya manusia yang relative besar (50\%) jumlahnya dalam suatu kegiatan rumah sakit. Pelayanan kesehatan yang baik dan berkualitas tidak terlepas dari peran tenaga medis dan non medis, salah satu di antaranya adalah tenaga perawat. Tenaga perawat mempunyai kedudukan penting dalam menghasilkan kualitas pelayanan kesehatan di rumah sakit, karena pelayanan yang diberikannya berdasarkan pendekatan bio-psiko-sosial-spiritual dan dilaksan akan selama 24 jam secara berkesinambungan (Depkes RI, 2001).

Perawat sendiri dikenal sebagai sosok yang lembut dalam melaksanakan pekerjaannya berdasarkan cinta kasih. Akan tetapi dalam kenyataannya, sering kita mendengar kritik dan kecaman dari masyarakat terhadap sistem pelayanan yang kurang bermutu, profesional atau kurang empati dalam melakukan program pelayanan kesehatan terutama di rumah sakit dan keluhan atas kinerja perawat dalam memberikan asuhan keperawatan. Oleh sebab itu perawat sebagai tim pelayanan kesehatan yang terbesar dituntut untuk meningkatkan mutu pelayanan keperawatan. Mutu pelayanan di rumah sakit juga ditinjau dari sisi keperawatan yang salah satunya meliputi aspek motivasi kerja (Sutopo, 2003).

Salah satu masalah yang ada dalam manajemen sumber daya manusia di rumah sakit adalah masalah kinerja karyawan. Kinerja karyawan dianggap penting bagi organisasi karena keberhasilan suatu organisasi dipengaruhi oleh kinerja itu 
sendiri. Kinerja atau prestasi kerja adalah hasil kerja yang dicapai oleh seorang karyawan dalam melakukan tugas sesuai tanggung jawab yang diberikan kepadanya. Dalam hal ini kinerja perawat merupakan aktivitas perawat dalam mengimplementasikan sebaik-baiknya suatu wewenang, tugas dan tanggung jawabnya dalam rangka pencapaian tujuan tugas pokok profesi dan terwujudnya tujuan dan sasaran unit organisasi (Slamet Haryono, 2004). Kinerja perawat sebenarnya sama dengan prestasi kerja di perusahaan. Perawat ingin diukur kinerjanya berdasarkan standar obyektif yang terbuka dan dapat dikomunikasikan. Jika perawat diperhatikan dan dihargai sampai penghargaan superior, mereka akan lebih terpacu untuk mencapai prestasi pada tingkat lebih tinggi (Neal, 2004).

Melihat begitu luas dan kompleksnya tugas dan fungsi dari perawat di rumah sakit, maka rumah sakit membutuhkan SDM yang profesional dalam melaksanakan tugas pokok dan fungsi yang menjadi tanggung jawab perawat dalam melayani pasien. Pelayanan keperawatan yang dilakukan kepada pasien di rumah sakit melalui asuhan keperawatan diharapkan menjadi berdaya guna dan berhasil guna. Kinerja perawat melalui pengelolaan asuhan keperawatan akan berhasil apabila memiliki tanggung jawab, mempunyai pengetahuan tentang manajemen keperawatan dan kemampuan memimpin orang lain di samping pengetahuan dan ketrampilan klinis yang harus dikuasainya pula (Nurachmad, 2001).

Berdasarkan hasil survey awal yang telah dilakukan peneliti rata-rata pendidikan terakhir adalah D3. Dari hasil observasi yang dilakukan terhadap kepala ruangan terlihat bahwa tidak semua kepala ruangan mampu memecahkan masalah yang ada di ruangan dengan baik, kepala ruangan sering mengambil keputusan tanpa berdiskusi dengan perawat diruangan. Berdasarkan wawancara terhadap 4 orang perawat pelaksana yang sedang bertugas di RSU. Sari Mutiara Lubuk Pakam, 2 dari mereka mengatakan kepala ruangan jarang memberikan arahan dan motivasi terhadap perawat pelaksana, 1 orang mengatakan kepala ruangan juga jarang bekerjasama dengan perawat pelaksana karena tugas asuhan keperawatan selalu dilakukan oleh perawat pelaksana dan 1 orang lagi mengatakan kepala ruangan jarang melakukan supervisi langsung dalam pelaksanaan tugas oleh perawat. Sedangkan hasil observasi yang dilakukan terhadap perawat pelaksana didapatkan bahwa perawat tidak melalukan pengkajian secara akurat dan menyeluruh terhadap data status bio, psiko, sosio dan spiritual pasien. Perawat tidak mengkaji ulang dan merevisi pelaksanaan tindakan keperawatan berdasarkan respon klien.

\section{METODE PENELITIAN}

Penelitian ini bersifat deskriptif korelasi. Dengan menggunakan pendekatan cross sectional yaitu untuk mengetahui hubungan kepemimpinan efetif kepala ruangan dengan kinerja perawat dalam melakukan asuhan keperawatan di RSU. Sari Mutiara Lubuk Pakam. Populasi dalam penelitian ini adalah seluruh perawat pelaksana yang bertugas di RSU.Sari Mutiara Lubuk Pakam yang berjumlah 55 responden. Sampel dalam penelitian ini adalah seluruh perawat pelaksana yang sedang bertugas di RSU.Sari Mutiara Lubuk Pakam, teknik pengambilan sampel dengan menggunakan total sampling berjumlah 55 responden. Instrumen yang digunakan dalam penelitian ini yaitu dengan kuisioner. Analisa data dalam penelitian ini meliputi analisa univariat yaitu untuk mengetahui distribusi frekuensi kepemimpinan efektif kepala ruangan dan kinerja perawat dalam melakukan asuhan keperawatan. Analisa bivariat untuk menilai hubungan kepemimpinan efektif kepala ruangan dengan kinerja perawat dalam melakukan asuhan keperawatan yaitu dengan menggunakan uji statistic chisquare dengan kepercayaan (CI) adalah $95 \%$ dimana bila $\mathrm{p}<0,05$, berarti hasil perhitungan bermakna (signifikan). 


\section{Analisa Univariat}

Untuk mengetahui distribusi frekuensi dan persentase Kepemimpinan Efektif Kepala Ruangan dan Kinerja Perawat dalam Melakukan Asuhan Keperawatan di RSU. Sari Mutiara Lubuk Pakam.

\section{Analisa Bivariat}

Analisa Hubungan Kepemimpinan Efektif Kepala Ruangan Dengan Kinerja Perawat dalam Melakukan Asuhan Keperawatan di RSU. Sari Mutiara Lubuk Pakam dengan menggunakan uji chi-square dan tingkat kepercayaan (CI) adalah 95\% dimana bila $\mathrm{p}<0,05$, berarti hasil perhitungan bermakna (signifikan).

\section{HASIL PENELITIAN}

A. Analisa Univariat

1. Karakteristik Responden Di Rumah Sakit Umum Sari Mutiara Lubuk Pakam.

\section{Tabel 4.1}

Distribusi Frekuensi Karakteristik Responden (Usia, Jenis Kelamin, Pendidikan Dan Lama Kerja) Di RSU Sari Mutiara Lubuk Pakam (n $=55$ )

\begin{tabular}{lll}
\hline Karakteristik Responden & $\mathrm{n}$ & $\%$ \\
\hline Usia & & \\
20-30 Tahun & 43 & 78.2 \\
>30 Tahun & 12 & 21.8 \\
\hline Jenis Kelamin & & \\
$\quad$ Laki-laki & 4 & 7.3 \\
$\quad$ Perempuan & 51 & 92.7 \\
\hline Pendidikan & & \\
Ners & 4 & 7.3 \\
D3 Kep & 51 & 92.7 \\
\hline Lama Kerja & & \\
1.5-3 Tahun & 31 & 56.4 \\
>3 Tahun & 24 & 43.6 \\
\hline
\end{tabular}

Berdasarkan tabel 4.1 dapat dilihat berdasarkan kelompok umur responden mayoritas berada pada rentang umur 20-30 tahun sebanyak 43 orang $(78,2 \%)$, pada jenis kelamin responden mayoritas perempuan sebanyak 51 orang $(92,7 \%)$, pada tingkat pendidikan responden mayoritas berada pada 9tingkat D3 Keperawatan sebanyak 51 orang
$(92,7 \%)$, lama kerja responden mayoritas 1,5 - 3 tahun yakni sebanyak 31 orang $(56,4 \%)$.

\section{Kepemimpinan Efektif Kepala Ruangan Di Rumah Sakit Umum Sari Mutiara Lubuk Pakam.}

Tabel 4.2

Distribusi Frekuensi Dan Persentase Kepemimpinan Efektif Kepala Ruangan di RSU Sari Mutiara Lubuk Pakam ( $\mathrm{n}=55)$

\begin{tabular}{lcc}
\hline Kepemimpinan efektif & $\mathrm{n}$ & $\%$ \\
\hline Efektif & 45 & 81.8 \\
Tidak Efektif & 10 & 18.2 \\
\hline
\end{tabular}

Berdasarkan tabel 4.2 dapat diketahui bahwa kepemimpinan kepala ruangan di RSU Sari Mutiara Lubuk Pakam mayoritas efektif yaitu $(81,8 \%)$.

\section{Kinerja Perawat Di Rumah Sakit Umum Sari Mutiara Medan}

Tabel 4.3

Distribusi Frekuensi dan Persentase Kinerja Perawat di RSU

Sari Mutiara Lubuk Pakam $(\mathrm{n}=55)$

\begin{tabular}{lcc}
\hline Kinerja Perawat & n & $\%$ \\
\hline Baik & 25 & 45.5 \\
Cukup & 28 & 50.9 \\
Kurang & 2 & 3.6 \\
\hline
\end{tabular}

Berdasarkan tabel 4.3 dapat diketahui bahwa kinerja perawat di RSU Sari Mutiara Lubuk Pakam mayoritas dalam kategori cukup yaitu $(50,9 \%)$.

\section{B. Analisa Bivariat}

\section{Tabel 4.4}

Hasil Uji Chi-Square Antara Kepemimpinan Efektif Kepala Ruangan Dengan Kinerja Perawat Di RSU. Sari Mutiara Lubuk Pakam. $(\mathrm{n}=55)$ 


\begin{tabular}{lccccccccc}
\hline Kepemimpinan & \multicolumn{6}{c}{ Kinerja Perawat } \\
\cline { 2 - 7 } \begin{tabular}{c} 
efektif kepala \\
\cline { 2 - 7 } \multicolumn{1}{c}{ ruangan }
\end{tabular} & Baik & \multicolumn{6}{c}{ Cukup } & \multicolumn{1}{c}{ Kurang } & \multicolumn{2}{c}{ Total } & $\mathrm{P}$ \\
\hline Efektif & 25 & 45.5 & 18 & 32.7 & 2 & 3.6 & 45 & 81.8 & .003 \\
Tidak efektif & - & - & 10 & 18.2 & - & - & 10 & 18.2 & \\
\hline \multicolumn{1}{c}{ Total } & 25 & 45.5 & 28 & 50.9 & 2 & 3.6 & 55 & 100 & \\
\hline
\end{tabular}

Berdasarkan tabel 4.4 dapat dilihat bahwa $(81,8 \%)$ kepemimpinan kepala ruangan dalam kategori efektif dengan kinerja perawat dalam kategori baik $(45,5 \%)$, kategori cukup $(32,7 \%)$ dan kategori kurang $(3,6 \%)$. Sedangkan dari $(18,2 \%)$ kepemimpinan kepala ruangan dalam kategori tidak efektif dengan kinerja perawat kategori cukup (18,2\%).

Setelah dilakukan uji chi-square dapat dilihat bahwa nilai $p$ value $=0.003$ menunjukkan bahwa ada hubungan yang signifikan antara kepemimpinan efektif kepala ruangan dengan kinerja perawat di RSU. Sari Mutiara Lubuk Pakam.

\section{PEMBAHASAN}

\section{Kepemimpinan Efektif Kepala Ruangan}

Dari hasil penelitian yang dilakukan terhadap 55 orang responden terlihat bahwa lebih banyak responden mengatakan kepemimpinan kepala ruangan efektif yaitu sebanyak 45 orang $(81,8 \%)$, dengan demikian respoden menilai bahwa kepala ruangan sudah bekerja dengan baik sesuai dengan fungsinya. Hal ini dapat terlihat dari jawaban kuesioner responden yang berpendapat kepala ruangan bisa memecahkan dan mengambil keputusan yang baik dari setiap masalah diruangan, kepala ruangan mau menerima saran dari perawat pelaksana serta berperan aktif dalam mengarahkan perawat pelaksana untuk bekerja sesuai tujuan unit. Hal ini menunjukkan bahwa kepala ruang telah mendapatkan apresiasi yang baik dari perawat pelaksana. Kepala ruang sebagai orang yang dihormati telah memberikan contoh yang baik bagi perawat pelaksana sehingga membuat kesan yang baik bagi perawat pelaksana. Hasil ini sesuai dengan pendapat Kurniawan yang mengatakan bahwa efektivitas adalah kemampuan melaksanakan tugas, fungsi (operasi kegiatan program dan visi) dari pada suatu organisasi atau sejenisnya yang tidak adanya tekanan dan ketegangan diantara pelaksanaanya (Kurniawan, 2005).

Kepemimpinan efektif merupakan kemampuan seorang pemimpin dalam memberikan keseimbangan antara pemberian tugas dan mengelola ketenagaan dan memfasilitasi pemecahan masalah dalam kesenjangan antara kemampuann, prosedur, struktur organisasi, dan motivasi (Dollan \&Sellwood, 2008). Hasil penelitian ini didukung oleh penelitian sebelumnya yang dilakukan oleh Apriyanto (2011) dengan hasil penelitian pada kepemimpinannya cukup baik yaitu sebagian besar 61 orang $(71,8 \%)$.

Beberapa responden mengatakan bahwa ada beberapa kepala ruangan yang tidak efektif yaitu 10 orang $(18,2 \%)$. Kepemimpinan yang tidak efektif dinilai karena kurangnya kompetensi kepala ruangan. Hal ini dapat terlihat dari jawaban kuesioner responden yang berpendapat dalam hal komunikasi kepala ruangan jarang mengingatkan perawat akan pentingnya pekerjaan yang dilakukan perawat pelaksana. Hal ini didukung oleh teori Wibowo yang mengatakan seorang pemimpin dikatakan efektif apabila dapat mencapai tujuanya. Agar mampu mencapai tujuan tersebut maka pemimpin diharapkan memiliki kompetensi yang sesuai dengan kepentingan organisasi. Di samping itu, masih banyak faktor yang mempengaruhi efektivitas kerja. Karena itu diperlukan pemimpin cerdas dan terampil, serta memiliki kompetensi (Wibowo, 2013).

Menurut Tappen (2004) inti dari kepemimpinan adalah kemampuan untuk memengaruhi orang lain. Kepemimpinan efektif merupakan pemenuhan dari tujuan bersama oleh pemimpin dengan bawahan. Seorang pemimpin yang efektif dalam keperawatan memiliki kualitas yang mencakup integritas, berani, insiatif, memiliki kekuatan, optimis, memiliki ketekunan, tenang, kemampuan mengatasi stress, dan kesadaran diri. Berdasarkan 
karakteristik responden usia, jenis kelamin, pendidikan dan lama kerja responden tidak memberikan pengaruh yang bermakna pada kepemimpinan efektif kepala ruangan.

Menurut asumsi peneliti berdasarkan kepemimpinan kepala ruangan diruang rawat inap RSU. Sari Mutiara Lubuk Pakam pemimpin yang efektif adalah pemimpin yang selalu terbuka untuk menerima saran dan kritikan dari orang lain, mampu berkomunikasi dengan baik, selalu berpikir kritis dalam setiap pemecahan masalah, serta mampu membuat perubahan dalam mencapai tujuan organisasi.

\section{Kinerja Perawat Dalam Melakukan Asuhan Keperawatan}

Dari hasil penelitian yang dilakukan terhadap 55 orang responden terlihat bahwa kinerja perawat kategori cukup yaitu sebanyak 28 orang $(50,9 \%)$, baik 25 orang $(45,5 \%)$ dan kurang 2 orang $(3,6 \%)$. Dengan demikian berarti perawat sudah mampu melakukan asuhan keperawatan dengan baik sesuai dengan prosedur keperawatan. Hal ini dapat dilihat dari jawaban kuesioner reponden yang menyatakan perawat selalu mengumpulkan dan mengelompokkan data bio-psiko-sosio dan spritual tentang pasien, perawat selalu melakukan analisis dan merumuskan masalah dengan mengacu pada diagnosis keperawatan, serta membuat rencana tindakan dan mencatat tindakan keperawatan yang dilaksanakan. Hal ini didukung oleh pendapat Mangkunegara (2009) Kinerja atau prestasi kerja adalah hasil kerja secara kualitas dan kuantitas yang dicapai seorang pegawai dalam melaksanakan tugasnya sesuai dengan tanggung jawab yang diberikan kepadanya.

Berdasarkan distribusi frekuensi, responden dalam penelitian ini sebagian besar berumur 21-30 tahun $(78,2 \%)$, perawat yang berusia >30 tahun sebesar $(21,8 \%)$. Perawat dengan kelompok usia tersebut dapat berdampak posistif terhadap rumah sakit jika dikelola dengan sistem manajemen sumber daya manusia keperawatan yang baik. Pelaksanaan asuhan keperawatan oleh perawat merupakan bentuk kinerja perawat yang bekerja di ruang rawat inap. Menurut Gibson (1996 dalam Rofii, 2012) bahwa umur dapat mempengaruhi kinerja dimana pengembangan karir terjadi pada usia 30 tahun, selain itu keterampilan seseorang terutama dalam hal kecepatan, kecekatan, kekuatan dan koordinasi dihubungkan dengan bertambahnya waktu. Umur 30 tahun merupakan tingkat perkembangan manusia yang dikategorikan usia dewasa muda (20-39 tahun), semakin bertambah usia berarti semakin arif dan bijaksana untuk melakukan suatu pekerjaan (Papalia, Olds \& Feldman, 2009).

Dilihat dari hasil distribusi frekuensi responden pada tingkat jenis kelamin sebagian besar adalah perempuan $(92,7 \%)$. Jenis kelamin yang kebanyakan menjadi perawat adalah perempuan. Menurut sejarahnya, keperawatan muncul dari peran perspektif perempuan dalam suatu keluarga, maka dianggap wajar bila perawat perempuan lebih banyak dari laki-laki (Rolinson, 2001). Adanya perbedaan jenis kelamin akan memberikan hasil kerja yang berbeda pula. Hal ini sesuai dengan rumah sakit lain pada umumnya, dimana sebagian besar perawat didominasi oleh kaum perempuan. Menurut (Stephen.P Robbins, 2001) dilain pihak terdapat pertimbangan lain bahwa perempuan dalam melaksanakan pekerjaannya lebih disiplin dalam mematuhi peraturan dibanding laki-laki, sehingga akan tercapai pelayanan keperawatan secara optimal.

Pendidikan responden dalam penelitian ini mayoritas berpendidikan D-III keperawatan sebesar $(92,7 \%)$ dan Ners sebesar $(7,3 \%)$, pendidikan merupakan salah satu karakteristik demografi yang dapat mempengaruhi seseorang, baik terhadap lingkungan maupun objek tertentu, selain itu pendidikan merupakan faktor tidak langsung yang berpengaruh pada kinerja (Ilyas, 2002). Semakin tinggi pendidikan akan semakin kritis, logis dan sistematis dalam berpikir sehingga meningkatkan kualitas kerjanya dengan kata lain semakin tinggi pendidikan 
seseorang maka semakin baik juga prestasi kerjanya.

Dalam penelitian ini lama kerja responden sebagian besar 1,5 - 3 tahun $(56,4 \%)$ dan responden yang bekerja >3 tahun sebesar $(43,6 \%)$, semakin lama masa kerja seseorang maka akan semakin banyak pengalaman yang dimilikinya terkait dengan pemberian asuhan keperawatan. Hasil penelitian ini didukung oleh pendapat Siagian (2009 dalam Rofii, 2009) yang mengatakan lama kerja mempengaruhi pengetahuan seseorang, semakin lama bekerja semakin banyak pengalaman sehingga produktivitas kerja dapat meningkat. Hal ini sejalan dengan teori Kusumawati (2011) yang mengatakan bahwa semakin banyak pengalaman yang dimiliki, maka akan semakin bertambah juga pengetahuan perawat tentang diri mereka, kesehatan klien, kemampuan untuk menginterpretasikan informasi tertentu dan melaksanakan tindakan keperawatan khususnya dalam memberikan asuhan keperawatan.

Hasil penelitian ini sesuai dengan penelitian yang dilaksanakan oleh Pitoyo (2000) tentang faktor-faktor yang berhubungan dengan kinerja perawat dalam melaksanakan perawatan kesehatan masyarakat di puskesmas kabupaten semarang. yang menyatakan ada hubungan yang bermakna antar kepemimpinan dengan kinerja perawat dalam melaksanakan asuhan perawatan.

Menurut asumsi peneliti berdasarkan kinerja perawat pelaksana di RSU. Sari Mutiara Lubuk Pakam bahwa kinerja yang baik akan mempengaruhi produktifitas sebuah organisasi. Setiap tindakan keperawatan yang dilakukan dengan mengacu pada standard asuhan keperawatan akan menghasilkan suatu kinerja yang baik.

\footnotetext{
Hubungan Kepemimpinan Efektif Kepala Ruangan Dengan Kinerja Perawat Dalam Melakukan Asuhan Keperawatan Di Rumah Sakit Umum Sari Mutiara Lubuk Pakam
}

Dari hasil uji statistik menggunakan uji chi-square menunjukkan bahwa ada hubungan antara kepemimpinan efektif kepala ruangan dengan kinerja perawat di RSU Sari Mutiara Lubuk Pakam dengan nilai p.value $<\alpha=0,05$ dimana nilai $p$.value $=$ 0,003 . Hal ini menunjukkan bahwa semakin baik kepemimpinan kepala ruangan semakin baik pula kinerja perawat di ruang rawat inap RSU. Sari Mutiara Lubuk Pakam.

Terlihat dari hasil penelitian yang menunjukkan bahwa lebih banyak responden mengatakan kepemimpinan kepala ruangan efektif yaitu sebanyak 45 orang $(81,8 \%)$ dengan kinerja perawat cukup yaitu sebanyak 28 orang $(50,9 \%)$. Hasil penelitian ini didukung penelitian sebelumnya yang dilakukan oleh sugijati (2008) dengan hasil penelitian kinerja perawat dalam melaksanakan asuhan keperawatan di ruang rawat inap RSUD Mataram dalam kategori baik (47\%). Menurut Kuntoro (2010), kepemimpinan dalam keperawatan sangatlah penting karena mempunyai pengaruh yang dapat menciptakan kepercayaan dan ketaatan, sehingga menimbulkan kesediaan untuk melaksanakan tugas, dalam rangka mencapai tujuan pelayanan keperawatan secara efektif dan efisien.

Kinerja perawat pelaksana yang baik menjadi indikator dari baiknya pekerjaan yang dihasilkan oleh perawat. Hasil kerja yang baik tersebut dapat diamati dari kompetensi dan produktivitas yang ditunjukan dari pelaksanaan pekerjaan yang dilakukan sesuai tugas pekerjaannya. Kinerja yang baik juga tercapai apabila pekerjaan dilakukan sesuai dengan prosedur yang ada dan pekerjaan dilakukan dengan kualitas hasil yang baik. Sesuai dengan Dessler (2009) menyebutkan kinerja karyawan dapat diukur dangan membandingkan hasil kerja dengan standar yang telah dibuat.

Kinerja perawat pelaksana di RSU. Sari Mutiara Lubuk Pakam yang sudah dalam kategori cukup perlu dipertahankan dan lebih ditingkatkan. Kinerja dapat dipertahankan dan ditingkatkan dengan memenuhi harapan perawat atas pola hubungan kerja yang baik, fasilitas kerja, iklim kerja, kebijakan 
kepemimpinan, pola kepemimpinan kerja dan kondisi kerja yang baik sehingga dapat mendukung tercapainya kinerja yang maksimal.

Beberapa penelitian membuktikan adanya hubungan ini seperti yang dilakukan oleh Oluseyi, S. (2009), menemukan bahwa kinerja karyawan sangat dipengaruhi oleh kepemimpinan efektif, kemudian motivasi kerja dan yang terakhir adalah manajemen waktu. Kemudian Baidowi, A (2010) mendapatkan kesimpulan bahwa budaya organisasi, kepemimpinan, insentif dan disiplin kerja secara simultan memengaruhi kinerja pegawai. Endro, dan Sujiono, M (2012) mendapatkan kesimpulan bahwa ada hubungan positif bermakna kepemimpinan terhadap kinerja tetapi ada hubungan tidak bermakna antara kepemimpinan terhadap kinerja melalui motivasi. Dari hasil penelitian yang diperoleh, maka peneliti dapat menyimpulkan semakin efektif kepemimpinan seorang kepala ruangan maka kinerja perawat juga akan semakin baik. Selain kepemimpinan yang efektif kinerja perawat juga dapat dipengaruhi oleh faktor lain seperti motivasi, beban kerja dan iklim kerja.

\section{KESIMPULAN}

Dari hasil penelitian yang telah dilakukan di ruang rawat inap RSU Sari Mutiara Lubuk Pakam dapat diperoleh kesimpulan sebagai berikut:

1. Kepemimpinan kepala ruangan di ruang rawat inap RSU Sari Mutiara Lubuk Pakam mayoritas adalah efektif. Hal ini menyatakan bahwa perawat menilai kepala ruangan di RSU Sari Mutiara Lubuk Pakam sudah bekerja dengan efektif sesuai dengan tugas dan fungsinya dalam ruangan.

2. Kinerja perawat di ruang rawat inap RSU Sari Mutiara Lubuk Pakam termasuk kategori cukup. Hal ini menyatakan bahwa perawat sudah mampu memberikan asuhan keperawatan terhadap pasien dan keluarga pasien sesuai dengan standar asuhan keperawatan.
3. Kepemimpinan efektif kepala ruangan ada hubungan dengan kinerja perawat dalam melakukan asuhan keperawatan di ruangan rawat inap RSU Sari Mutiara Lubuk Pakam dengan p.value $=0.003<\alpha$ $=0,005$. Hal ini menunjukkan bahwa semakin baik kepemimpinan seorang kepala ruangan maka akan semakin baik pula kinerja perawat dalam melakukan asuhan keperawatan, karena seorang pemimpin yang efektif akan mampu mempengaruhi orang lain kearah tujuan yang lebih baik.

\section{SARAN}

1. Bagi Kepala Ruangan

Disarankan agar bekerja sesuai dengan tugas dan fungsinya sebagai pemimpin yang efektif seperti mampu berpikir kritis, mengambil tindakan dan memecahkan masalah, menyusun tujuan dan membangun orang lain serta lebih memperhatikan para perawat tentang pentingnya kinerja yang baik dalam suatu tindakan keperawatan dengan cara lebih menekankan tentang penerapan standar asuhan keperawatan kepada pasien maupun keluarganya.

2. Bagi Perawat Pelaksana

Disarankan agar dapat menjaga hubungan yang baik dengan kepala ruangan dan lebih meningkatkan kinerjanya dalam melakukan asuhan keperawatan terhadap pasien maupun keluarga dengan cara selalu mengaplikasikan standar asuhan keperawatan dalam setiap tindakan keperawatan.

3. Bagi Rumah Sakit

Disarankan kepada pihak manajemen rumah sakit agar lebih selektif dalam memilih kepemimpinan kepala ruangan dan perawat pelaksana yang memiliki pengetahuan lebih luas guna terciptanya kinerja perawat yang berkualitas. Pihak rumah sakit juga diharapkan lebih meningkatkan iptek dengan menyelenggarakan pelatihan tentang kepemimpinan yang efektif bagi kepala ruangan dan pelatihan tentang penerapan 
asuhan keperawatan yang baik bagi perawat pelaksana.

4. Bagi Peneliti Selanjutnya

Disarankan agar menggunakan metode lain dalam melakukan penilaian kinerja perawat seperti observasi untuk mendapatkan hasil yang lebih maksimal dan tidak bersifat objektif.

\section{REFERENSI}

Agung, Kurniawan. (2005). Transformasi Pelayanan Publik. Yogyakarta: Pembaharuan.

Depkes RI, (2001). Petunjuk Pelaksanaan Indikator Pelayanan Rumah Sakit, Departemen Kesehatan Republik Indonesia, Jakarta.5

Dessler Gary, (2009). Manajemen Sumber Daya Manusia, Jakarta :Edisi Kesepuluh Jilid Dua PT Indeks

Harahap, Nazlah (2012). Pengaruh Kepemimpinan dan Komunikasi terhadap Kinerja Perawat Pelaksana di Ruang Rawat Inap RSUD Kota Padangsidimpuan. Diakses pada hari Kamis, 09 Juni 2016.http://repository.usu.ac.id/handle/ $123456789 / 34028$

Ilyas, Yaslis, (2002). Kinerja, Teori, Penilaian dan Penelitian. Fakultas Kesehatan Masyarakat Universitas Indonesia. Jakarta.

Kuntoro, A. (2010). Buku Ajar Manajemen Keperawatan.

Yogyakarta: Nuha Medika

Nurachmad E., (2001). Asuhan Keperawatan Bermutu di Rumah Sakit. Jakarta : http//www.pdpersi.co.id

Robbin, S.P. (2006). Perilaku Organisasi, Jilid I, (Edisi ke-10 terjemahan), PT. Gramedia, Jakarta.

Tappen, R. M., Weiss, S. A., Whitehead, D. K. (2004). Essentials of Nursing Leadership and Management. Philadelphia. F. A. Davis Company.

Wibowo. (2013). Manajemen Kinerja. Jakarta: Rajawali Pers 